\title{
Water quality and avian inputs as sources of isotopic variability in aquatic macrophytes and macroinvertebrates
}

\author{
Esther SEBASTIÁN-GONZÁLEZ, ${ }^{1,2 *}$ Joan NAVARRO,${ }^{3}$ José Antonio SÁNCHEZ-ZAPATA, ${ }^{1}$ Francisco BOTELLA, ${ }^{1}$ \\ and Antonio DELGADO ${ }^{4}$
}

\author{
${ }^{1}$ Ecology Area, Department of Applied Biology, Miguel Hernández University, E-03202 Elche, Alicante, Spain; ${ }^{2}$ Doñana Biological \\ Station (EBD-CSIC), E-41092 Sevilla, Spain; ${ }^{3}$ Institut de Ciències del Mar (ICM-CSIC) E-08003 Barcelona, Spain; \\ ${ }^{4}$ Instituto Andaluz de Ciencias de la Tierra, (IATC-CSIC-UGR), E-18100 Granada, Spain \\ *Corresponding author: esebastian@umh.es
}

\begin{abstract}
Different factors can affect the isotopic values of aquatic organisms. Nevertheless, water quality may be very important for aquatic organisms because they directly depend on it. In this article, we aimed to investigate if variations in the chemical and biological water characteristics affect the stable isotope values of aquatic organisms. We also wished to discuss alternative sources of isotopic variability. We analysed the water chemical characteristics, the input of extra nitrates from bird guano, and the $\delta^{15} \mathrm{~N}$ and $\delta^{13} \mathrm{C}$ values for the macroinvertebrates and macrophytes present in freshwater irrigation ponds. Variability in the values of the analysed stable isotopes was high, even for the same species in different ponds. Water conductivity, nitrates, ammonium, organic nitrogen concentrations and COD (Chemical Oxygen Demand) directly correlated with the isotopic values. Besides, the input of extra nitrates from Larids' (gulls and terns) guano might also increase the $\delta^{15} N$ values at the ponds which these birds most intensively use. Nevertheless, the high $\delta^{15} N$ values are difficult to explain in terms of water characteristics and excrements inputs and only general processes of denitrification could explain these values. Longer water residence times could cause extremely enriched isotopic values in both DIC (Dissolved Inorganic Carbon) and dissolved nitrates. This study shows different sources of isotopic variability which can prove useful to interpret stable isotopes studies.
\end{abstract}

Key words: stable isotope, water, agriculture, invertebrates, irrigation pond.

Received: October 2011. Accepted: December 2011.

\section{INTRODUCTION}

Stable isotope analyses of nitrogen (denoted as $\delta^{15} \mathrm{~N}$ ) and carbon (denoted as $\delta^{13} \mathrm{C}$ ) have provided significant insights into trophic web studies. They are a powerful ecological tool to look at processes, connections and possible factors that influence both terrestrial and aquatic ecosystems (Fry 1991; Hamilton et al. 1992; Michener, and Scherr 1994; Fair, and Heikoop 2006, Sierzen et al. 2006). The principle underlying this approach is that the $\delta^{15} \mathrm{~N}$ and $\delta^{13} \mathrm{C}$ values recorded for consumers predictably reflect those of their prey (Michener, and Schell 1994). The $\delta^{15} \mathrm{~N}$ values usually show a stepwise enrichment with each trophic level, providing a reliable trophic position of organisms within the community (Hobson, and Welch 1992; Michener, and Schell 1994; Kelly 2000; Tamelander et al. 2006). The $\delta^{13} \mathrm{C}$ values vary among primary producers with isotopically distinct sources (i.e., different photosynthetic pathways in $\mathrm{C}_{3}$ vs $\mathrm{C}_{4}$ plants; Kelly 2000; Gichuki et al. 2001), but change very slightly between trophic levels (Hobson et al. 1995). Therefore, $\delta^{13} \mathrm{C}$ can be used to determine ultimate sources of carbon in diets (Post 2002; Søreide et al. 2006).

In freshwater systems, the most direct way to assess the basal isotopic level is to measure the $\delta^{15} \mathrm{~N}$ and $\delta^{13} \mathrm{C}$ values of primary producers. Nevertheless, these systems present a temporal and spatial variation in their physicochemical characteristics, which makes the interpretation of the isotopic results difficult (Cabana, and Rasmussen 1996; Vander Zanden, and Rasmussen 1999; Finlay et al. 2002; Post 2002; Howard et al. 2005). The reasons for the variability observed in isotopic values may include differences in baseline hydrologic characteristics or nutrient enrichment (Cabana, and Rasmussen 1996; Finlay et al. 2002; Post 2002; Sierzen et al. 2006; Vander Zanden, and Rasmussen 1999). For example, either high conductivity decreases stomatal conductance, which leads to a more enriched $\delta^{13} \mathrm{C}$ (Kao et al. 2001), or nitrification processes in water could increase the $\delta^{13} \mathrm{C}$ values in aquatic plants (Finlay, and Kendall 2007).

Pond networks have been largely used as study models to test biological and ecological hypotheses. Although structurally simple, they are not homogeneous, and they perform biologically as real islands surrounded by a nonavailable matrix for lots of organisms (De Meester et al. 2005; Céréghino et al. 2008). In SE Spain, around 2700 irrigation ponds have been constructed in the last 30 years to store water for agricultural purposes (Sánchez-Zapata 
et al. 2005). Besides, the man-orientated use of these ponds as water reservoirs, a community of aquatic macrophytes and macro-invertebrates has colonised these ponds and has used them on a regular basis (Abellán et al. 2006). The ponds are filled with water which originates from diverse sources, such as interbasin river transfers, sewage plants, wells, or from combinations of these origins. Therefore, their chemical properties clearly differ. The residence time of water is also variable, and biogeochemical processes may occur (Mariotti et al. 1988; Robinson 2001). Moreover, several seabirds species, mainly Larids (gulls and terns), use these artificial habitats to feed or to rest in (Sánchez-Zapata et al. 2005; Sebastián-González et al. 2010), and they provide an important amount of nitrates through their depositions, which could increase the $\delta^{15} \mathrm{~N}$ values in the ponds they use more intensively (Haney et al. 1998; Keatley et al. 2009). This system can be used to investigate the potential effect of water characteristics and usage on the isotopic signatures of the species present in the ponds.

The main objective of this study was to examine if the chemical and biological water characteristics affect the $\delta^{15} \mathrm{~N}$ and $\delta^{13} \mathrm{C}$ values for macrophytes and macroinvertebrates in a network of fresh-water ponds. In particular, the main aims were to: (1) describe the isotopic values of several macrophytes and macroinvertebrates species in a fresh-water network of ponds; (2) investigate the potential relationships between water characteristics and the isotopic values for macrophytes and macroinvertebrates; and (3) evaluate the potential effect of the input of extra nitrates from Larids on the stable isotope values for macrophytes and macroinvertebrates.

\section{MATERIALS AND METHODS}

Study area

The study was conducted in the Vega Baja Valley in SE Spain. In the 1980s, an interriver water transfer was built to bring water to the area for irrigation purposes. Since then, 2700 ponds have been constructed to store the water received from the water transfer, and the area has become a mosaic of crop fields and artificial wetlands. These ponds can achieve a high degree of naturalisation with time and may function ecologically as a network of real wetlands for some of the waterbird, amphibian, macroinvertebrate and macrophyte species using them (see Sánchez-Zapata et al. 2005; Abellán et al. 2006; Sebastián-González et al. 2010 for more information). The area comprises 95,840 ha and has a Mediterranean semiarid climate, with low annual rainfall $(300 \mathrm{~mm})$ and warm mean annual temperatures $\left(18^{\circ} \mathrm{C}\right)$. The landscape is dominated by intensive agriculture (citrus and vegetables), palm trees (Phoenix dactylifera), small towns and sparse houses (Sanchez-Zapata et al. 2005).
Sample collection and water quality determination

We sampled plants and macroinvertebrates in 25 irrigation ponds, which were randomly selected from the 2700 ponds in the study area. The average distance between ponds was 9295 metres. The distance to the closest pond ranged between 161 and 9964 metres. Healthy green parts of different macrophytes were collected and identified with their main group (Cladophora, Potamogeton, Chara, Najas maritima, Ullothrix, Enteromorpha, Zannichellia and Oscillatoria). Macro-invertebrates were sampled with a D-frame net (500-mm mesh) from sediment. Afterwards, benthic organisms were collected by the kick-sampling methodology. Invertebrate samples were preserved in $70 \%$ ethanol and returned to the laboratory for identification (Dytiscidae, Naucoridae, Corixidae, Decapoda, Hydrophilidae and Chironomidae). The nitrates, COD (Chemical Oxygen Demand), ammonium and nutrient ions of the water collected in each sampled pond were determined in the laboratory (Tab. 1) by standard techniques (Greenberg et al. 1992). All macrophytes, macroinvertebrates and water samples were collected at the same time in all 25 ponds in June 2003.

Guano inputs influence on $\delta^{15} \mathrm{~N}$ values

We explored the potential effects caused by the guano deposited by Larids (gulls and terns) on the $\delta^{15} \mathrm{~N}$ values for the macrophytes and macroinvertebrates present in the irrigation ponds. Larids breed in the natural wetlands in the study area, and they use irrigation ponds to forage or to rest in (but not to nest). We quantified the pond use of seven common Larid species; Audouin's gull (Ichthyaetus audouinii), yellow-legged gull (Larus michahellis), blackheaded gull (Chroicocephalus ridibundus), common tern (Sterna hirundo), little tern (S. albifrons), whiskered tern (Chlidonias hibridus) and gullbilled tern (Gelochelidon nilotica). These species stay at the same pond for long periods for foraging or resting purposes. Therefore, the ponds that have been used by these species for a long time

Tab. 1. Values (mean, SD, min. and max.) of physical and chemical parameters measured in the water of the sampled irrigation ponds.

\begin{tabular}{lcc}
\hline & Mean \pm SD & Range \\
\hline Conductivity $\left(\mu \mathrm{S} \mathrm{cm}^{-1}\right)$ & $1884.87 \pm 652.75$ & $884 ; 3800$ \\
Sodium $\left(\mathrm{mg} \mathrm{L}^{-1}\right)$ & $180.82 \pm 102.58$ & $45 ; 425$ \\
Potassium $\left(\mathrm{mg} \mathrm{L}^{-1}\right)$ & $12.38 \pm 10.93$ & $2.8 ; 49.2$ \\
Calcium $\left(\mathrm{mg} \mathrm{L}^{-1}\right)$ & $133.86 \pm 47.99$ & $79 ; 251$ \\
Magnesium $\left(\mathrm{mg} \mathrm{L}^{-1}\right)$ & $79.12 \pm 30.98$ & $36.5 ; 172.2$ \\
Bicarbonates $\left(\mathrm{mg} \mathrm{L}^{-1}\right)$ & $167.48 \pm 67.00$ & $78.5 ; 340.1$ \\
Nitrates $\left(\mathrm{mg} \mathrm{L}^{-1}\right)$ & $10.65 \pm 14.50$ & $0 ; 65$ \\
Total organic nitrogen $\left(\mathrm{mg} \mathrm{L}^{-1}\right)$ & $26.50 \pm 56.22$ & $1 ; 315$ \\
Chemical Oxygen Demand & & \\
$\quad(\mathrm{COD})\left(\mathrm{mg} \mathrm{O}_{2} \mathrm{~L}^{-1}\right)$ & $23.11 \pm 12.37$ & $2 ; 60$ \\
Amonium $\left(\mathrm{mg} \mathrm{L}^{-1}\right)$ & $2.82 \pm 4.43$ & $0 ; 13$ \\
\hline
\end{tabular}


may present increased $\delta^{15} \mathrm{~N}$ values for the macrophytes and macroinvertebrates as a result of guano input (see Haney et al. 1998). In order to quantify pond usage by Larids, we calculated the average percentage of the times all 25 ponds sampled had been used by these species in surveys performed during the breeding season over a 6 year period. Each pond was visited once a year and all the waterbirds present were counted (See Sebastián-González et al. 2010 for more information about the surveys).

Isotopic determination

Macroinvertebrates from the same pond and taxonomic group were pooled prior to the isotopic analyses. Samples were rinsed with distilled water and freeze-dried for 48 hours. They were ground to powder; $0.7 \mathrm{mg} \mathrm{sub-}$ samples of homogenised material were loaded in tin cups and combusted at $1020^{\circ} \mathrm{C}$. The $\delta^{15} \mathrm{~N}$ and $\delta^{13} \mathrm{C}$ values were measured using a Carlo Erba EA1500 NC elemental analyzer on-line with a Finnigan Delta Plus XL mass spectrometer (Termo Finnigan, Brehmen, Germany). Stable isotope abundance was expressed in standard $\delta$ notation relative to $\mathrm{V}$-PDB and AIR (Atmospheric $\mathrm{N}_{2}$ ) for $\mathrm{C}$ and $\mathrm{N}$, respectively. V-PDB is the Vienna international standard series (supplied by the IAEA) $v s$ the classical calcite standard from Pee Dee Belemnite (PDB). The $\delta^{15} \mathrm{~N}$ and $\delta^{13} \mathrm{C}$ values were calculated as:

$$
\delta \mathrm{X}=\left[\left(\mathrm{R}_{\text {sample }} / \mathrm{R}_{\text {standard }}\right) 1\right] \times 1000
$$

where $\mathrm{R}=\left({ }^{13} \mathrm{C} /{ }^{12} \mathrm{C}\right.$ or $\left.{ }^{15} \mathrm{~N} /{ }^{14} \mathrm{~N}\right)$ of the sample and standards, respectively. All the samples were analysed in duplicate and two internal standards were measured for every ten samples. Based on numerous inorganic and organic international reference standards measurements, the analytical precision was determined to be about $\pm 0.1 \%$ ( $1 \sigma)$ for $\delta^{15} \mathrm{~N}$ and $\delta^{13} \mathrm{C}$.
Statistical analysis

We grouped macrophytes into two groups; macrophytes with floating parts (Cladophora, and Potamogeton) and submerged macrophytes (Chara, Najas maritima, Ullothrix, Enteromorpha, Zannichellia and Oscillatoria). We also classified macroinvertebrates depending on their feeding strategies as predators (Dytiscidae, Hydrophilidae and Naucoridae) or as omnivores/detritivores (Corixidae, Decapoda and Chironomidae). All the hydrophilidae individuals were collected as juveniles.

We used non-parametric tests, performed with the SPSS 15.0 software, to compare the isotopic values of both macrophytes and macroinvertebrates. Generalised linear models (GLMs; McCullagh, and Nelder 1989), using the R 2.1.1 software (R Development Core Team, http://www.r-project.org), were employed to relate the $\delta^{15} \mathrm{~N}$ and $\delta^{13} \mathrm{C}$ values (as the dependent variables) to water quality (as the independent variable). Moreover, in order to ascertain whether the isotopic values were, in some way, related to the pond's hydrological proprieties, we also used GLMs to relate the isotopic values with the pond identification number. GLMs enable the use of suitable error distributions, and some of the limitations of conventional regression models were avoided. Poisson distribution was used. We performed univariate models (with one predictor variable). As we performed several analyses, we applied a Bonferroni correction and we set the statistical significance at $p=0.004$ for the analyses.

\section{RESULTS}

Stable isotope values of macrophytes and macroinvertebrates

The overall variation in isotopic values for macrophytes and macroinvertebrates was very high, ranging from $0.98 \%$ to $25.03 \%$ for $\delta^{15} \mathrm{~N}$ and from $30.71 \%$ o to

Tab. 2. $\delta^{15} \mathrm{~N}$ and $\delta^{13} \mathrm{C}$ values of all macroinvertebrates and macrophytes species sampled in the irrigation ponds. We represent the mean, the standard deviation and the range (min. and max. measured values).

\begin{tabular}{|c|c|c|c|c|c|c|}
\hline Group & Taxonomic group & $\mathrm{N}$ & $\delta^{15} \mathrm{~N} \% \mathrm{\pm} \pm \mathrm{SD}$ & Range & $\delta^{13} \mathrm{C} \%{ }_{0} \pm \mathrm{SD}$ & Range \\
\hline \multirow[t]{5}{*}{ Macroinvertebrate } & Corixidae & 8 & $12.04 \pm 4.29$ & $7.4 ; 20.1$ & $-25.04 \pm 3.39$ & $-30.7 ;-21.1$ \\
\hline & Decapoda & 1 & 4.93 & - & -16.16 & - \\
\hline & Hydrophilidae & 5 & $16.63 \pm 2.05$ & $13.9 ; 18.5$ & $-23.56 \pm 1.60$ & $-25.5 ;-22.1$ \\
\hline & Naucoridae & 7 & $11.05 \pm 4.10$ & $4.7 ; 17.6$ & $-21.82 \pm 3.27$ & $-27.1 ;-18.6$ \\
\hline & Chironomidae & 5 & $16.01 \pm 6.23$ & $5.9 ; 22.7$ & $-21.96 \pm 4.43$ & $-28.9 ;-16.9$ \\
\hline \multirow[t]{8}{*}{ Macrophyte } & Chara & 2 & $3.99 \pm 0.69$ & $3.5 ;-4.4$ & $-11.77 \pm 0.34$ & $-12.0 ;-11,5$ \\
\hline & Cladophora & 2 & $17.56 \pm 7.22$ & $12.4 ; 22.6$ & $-14.22 \pm 0.46$ & $-14.5 ;-13.8$ \\
\hline & Enteromorpha & 2 & $13.20 \pm 7.28$ & $4.7 ; 17.4$ & $-15.82 \pm 11.09$ & $-27.9 ;-6.2$ \\
\hline & Najas maritima & 1 & 0.98 & - & -12.05 & - \\
\hline & Oscillatoria & 1 & 2.00 & - & -25.51 & - \\
\hline & Potamogeton & 6 & $9.71 \pm 8.84$ & $1.9 ; 25.0$ & $-14.54 \pm 4.12$ & $-20.7 ;-9.9$ \\
\hline & Ulothrix & 1 & 12.36 & - & -18.59 & - \\
\hline & Zannichellia & 1 & 6.33 & - & -12.35 & - \\
\hline
\end{tabular}




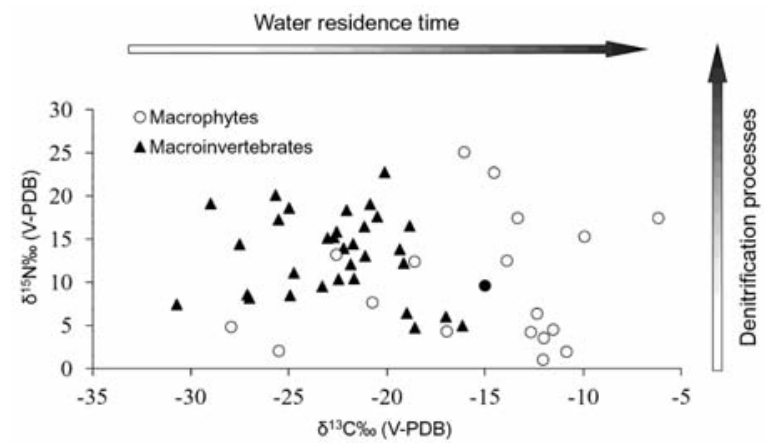

Fig. 1. $\delta^{15} \mathrm{~N}$ and $\delta^{13} \mathrm{C}$ isotopic values of macrophytes and macroinvertebrates sampled in the irrigation ponds. Effects of denitrification and preferential fixation of $13 \mathrm{C}$ during photosynthesis (increasing resident time of the water) are show for comparison.

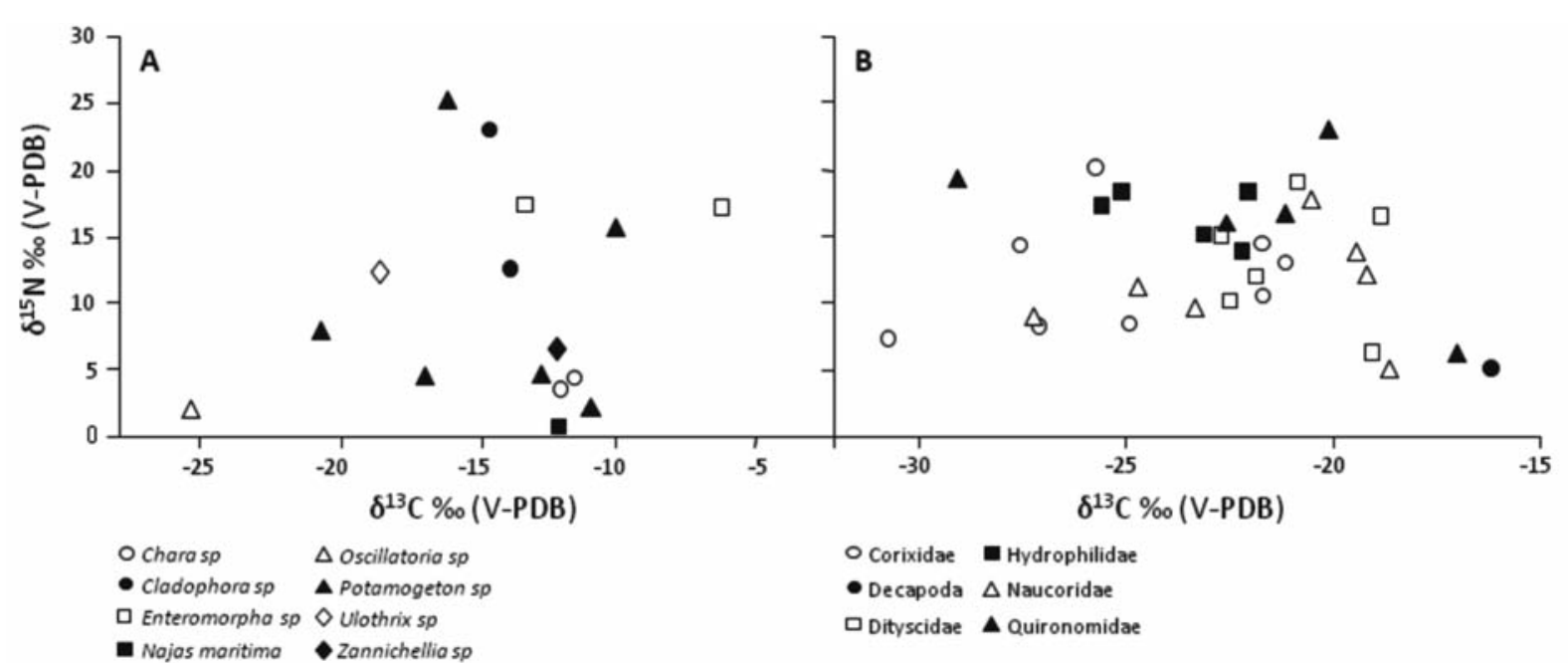

Fig. 2. $\delta^{15} \mathrm{~N}$ and $\delta^{13} \mathrm{C}$ values of the species of (A) macrophytes and (B) macroinvertebrates sampled in the irrigation ponds.

$6.18 \%$ for $\delta^{13} \mathrm{C}$ (Tab. 2). This high variability was observed not only among the different taxa, but also within the individuals of the same taxonomic group and at the species level (Figs 1 and 2). Within the macrophytes species, we also found significant variability in both the $\delta^{15} \mathrm{~N}$ and $\delta^{13} \mathrm{C}$ values (Fig. 2a). For example, Potamogeton varied up to $23 \%$ units in the $\delta^{15} \mathrm{~N}$ and $10 \%$ units in the $\delta^{13} \mathrm{C}$ values. Macroinvertebrates' isotopic values presented a lower range of variation than those of the macrophytes species (Fig. 2b). Moreover, the average $\delta^{15} \mathrm{~N}$ values for macroinvertebrates were significantly higher than those for macrophytes, while the average $\delta^{13} \mathrm{C}$ values were more negative (Mann-Witney U-test, both U $<171.00$; both $p<0.05)$. No significant differences were found in the isotopic values obtained between the submerged and floating macro-phytes species (U-test, both $p$ $>0.4$ ), and between predators and omnivores/detritivores for macroinvertebrates (both $p>0.1$ ), (Tab. 3).
Effect of water characteristics on stable isotope values

We found a high variability in all the parameters measured in the water ponds (Tab. 1). The $\delta^{15} \mathrm{~N}$ values related to the pond identification number (GLMs, both $p<0.05$. Explained deviance: macrophytes $4.4 \%$, macroinvertebrates $13.6 \%$ ). Nevertheless, the $\delta^{13} \mathrm{C}$ values did not relate to the pond number (GLMs, both $p>0.05$ ). The isotopic values of the species using irrigation ponds also seemed to be determined by the water characteristics in the ponds. We found significant relationships among $\mathrm{pH}$, sodium, potassium, calcium, nitrates, ammonium, organic nitrogen, the Chemical Oxygen Demand (COD) and the $\delta^{15} \mathrm{~N}$ isotopic values for macrophytes (Tab. 4). Differences were also noted between the floating and submerged macrophytes in the models, whose isotopic values related to water characteristics. The deviance of the models for floating macrophytes was, in general, greater than for sub- 
Tab. 3. $\delta 15 \mathrm{~N}$ and $\delta 13 \mathrm{C}$ values of macroinvertebrates and macrophytes species grouped per habitat and foraging ecology. We represent the mean, the standard deviation and the range (min. and max. measured values). Macroinvertebrates; predators (Dytiscidae, Hydrophilidae and Naucoridae) and omnivores/detritivores (Corixidae, Decapoda and Chironomidae). Macrophyte; submerged (Chara, Enteromorpha, Ulothrix, Najas maritima, Zannichellia and Oscillatoria), floating (Potamogeton and Cladophora).

\begin{tabular}{|c|c|c|c|c|c|c|}
\hline Group & Habitat & $\mathrm{N}$ & $\delta^{15} \mathrm{~N} \% \mathrm{~m} \pm \mathrm{SD}$ & Range & $\delta^{13} \mathrm{C} \%{ }_{00} \pm \mathrm{SD}$ & Range \\
\hline Macroinvertebrate & Predators & 19 & $12.89 \pm 4.59$ & $4.6 ; 19.0$ & $-21.70 \pm 2.79$ & $-27.1 ;-16.2$ \\
\hline Macroinvertebrate & Omnivores/detritivores & 13 & $13.56 \pm 5.26$ & $5.9 ; 22.7$ & $-23.85 \pm 3.95$ & $-30.7 ;-16.9$ \\
\hline Macrophyte & Submerged & 8 & $7.69 \pm 6.38$ & $1.0 ; 17.4$ & $-15.50 \pm 7.12$ & $-27.9 ;-6,2$ \\
\hline Macrophyte & Floating & 8 & $11.67 \pm 8.74$ & $1.9 ; 25.0$ & $-14.46 \pm 3.49$ & $-9.9 ;-20.7$ \\
\hline Macroinvertebrate & - & 32 & $13.16 \pm 4.81$ & $4.6 ; 22.7$ & $-22.57 \pm 3.43$ & $-30.7 ;-16.2$ \\
\hline Macrophyte & - & 16 & $9.86 \pm 7.76$ & $0.9 ; 25.0$ & $-14.20 \pm 4.60$ & $-6.2 ;-25.5$ \\
\hline
\end{tabular}

merged ones. Besides, the $\delta^{15} \mathrm{~N}$ values for macroinvertebrates produced significant relationships with conductivity, bicarbonate, nitrates, ammonium, organic nitrogen and COD for omnivores and detritivores. Meanwhile, none of the water characteristics studied related to the $\delta^{15} \mathrm{~N}$ value of predators (Tab. 4). Moreover, the $\delta^{13} \mathrm{C}$ values of both macrophytes and macroinvertebrates did not relate to any of the water characteristics.

\section{Larids influence}

A significantly positive relationship was found between the ponds used by seabirds (average percentage of times a pond had been used by Larids in the 6 study years) and the $\delta^{15} \mathrm{~N}$ values for macrophytes (Pearson's correlation test, $R=0.36 ; p=0.04)$. Nevertheless, the relationship found for macroinvertebrates was not significant $(R=0.19$; $p=0.46$ ).

\section{DISCUSSION}

Isotopic values

The present study reports considerable isotopic variability for both the $\delta^{15} \mathrm{~N}$ and $\delta^{13} \mathrm{C}$ values in a network of freshwater ponds. As expected, macroinvertebrates show higher mean $\delta^{15} \mathrm{~N}$ values than macrophytes. The diet of the studied macroinvertebrates is composed of macrophytes and other invertebrates, which is reflected at a higher trophic level with, therefore, higher $\delta^{15} \mathrm{~N}$ values (Hobson, and Welch 1992; Michener, and Schell 1994; Kelly 2000, Tamelander et al. 2006). The lower mean $\delta^{13} \mathrm{C}$ value obtained for macroinvertebrates compared to aquatic macrophytes can be explained by consumption of terrestrial material, which is generally more negative than most aquatic vascular plants, or by their carbon metabolic routes being different.

Moreover, other sources of variability among macrophytes and macroinvertebrates have been found. Several studies have demonstrated major differences in the isotopic values of the same species among different study sites (Alexander et al. 1996; Cabana, and Rasmussen 1996; Harvey, and Kitchell 2000). Nevertheless, there is very little information available about variation in isotope values within the same ecosystem (Syväranta et al. 2006). Stable isotopes of macrophytes and macroinvertebrates in irrigation ponds show high variability, even among the same species. The $\delta^{15} \mathrm{~N}$ values of some macrophytes (Enteromorpha and Ulothrix) and some macroinvertebrates (Chiromonidae, Naucoridae, Corixidae and Hydrophilidae) in irrigation ponds were higher than those reported

Tab. 4. GLMs between the macrophytes and macroinvertebrates $\delta^{15} \mathrm{~N}$ isotopic values, and the water biochemical characteristics. We show the percentage of explained devi-ance and the significance of the univariant models. We performed separated models for the plants that were completely submerged and for those with some floating parts. We also separated models for the predators and for the omnivores/detritivores, but none of the variables were significant for the predators. All the significant models had a positive coefficient except the model for the $\mathrm{pH}$ for submerged macrophytes, and the model for the organic nitrogen for macroinvertebrates. None of the models for the $\delta^{13} \mathrm{C}$ was significant. p-values: $* \mathrm{p}<0.005, * * p<0.001$.

\begin{tabular}{|c|c|c|c|c|c|c|}
\hline & \multicolumn{2}{|c|}{ Floating } & \multicolumn{2}{|c|}{ Submerged } & \multicolumn{2}{|c|}{ Omnivores/Detritivores } \\
\hline & $\%$ Deviance & $p$ & $\%$ Deviance & $p$ & $\%$ Deviance & $p$ \\
\hline $\mathrm{pH}$ & 80.49 & * & - & - & - & - \\
\hline Sodium & 75.05 & * & 24.49 & * & - & - \\
\hline Potassium & 72.93 & * & - & - & - & - \\
\hline Calcium & 80.33 & * & - & - & - & - \\
\hline Bicarbonate & - & - & - & - & 41.05 & $* *$ \\
\hline Nitrates & 64.37 & $*$ & 19.97 & $*$ & 33.54 & $* *$ \\
\hline Ammonium & 65.54 & $*$ & - & - & 18.57 & $*$ \\
\hline Organic Nitrogen & - & - & 21.52 & $*$ & 22.41 & $*$ \\
\hline COD & 74.63 & $*$ & 34.03 & $* *$ & 36.24 & $* *$ \\
\hline
\end{tabular}


in previous studies in natural and artificial freshwater habitats (Dunton 2001; Spencer et al. 2003; Grey et al. 2004; Tavares et al. 2008).

On the other hand, the $\delta^{13} \mathrm{C}$ values for Potamogeton varied even more so than in other studies that already reported very high variability (15 units, Alexander et al. 1996, 16 units, Gichuki et al. 2001). This high variability in the $\delta^{13} \mathrm{C}$ values for Potamogeton may be related to the plant's development status. In general, submerged plants typically have an enriched $\delta^{13} \mathrm{C}$ signature because their source of dissolved inorganic carbon (DIC) is limited and, usually, in arid systems less negative than the atmospheric $\mathrm{CO}_{2}$. In this sense, Potamogeton starts life submerged, but a more developed plant contains floating leaves, which change the isotopic $\delta^{13} \mathrm{C}$ value to a more depleted one. Syväranta et al. (2006) detected high variability in the $\delta^{15} \mathrm{~N}$ values for macrophytes, which can potentially increase isotopic variation in herbivores feeding upon these macrophytes. This can also be the case of irrigation ponds, where high variability in macrophytes may have an effect on the isotopic values of the macroinvertebrates feeding on them. Moreover, the higher mean $\delta^{15} \mathrm{~N}$ isotopic value of omnivore/detritivore macroinvertebrates compared to predator macroinvertebrates suggests that other variables, apart from differences in the trophic level, may be important to determine their isotopic values.

\section{Effect of water characteristics}

Stable isotopes can prove to be a useful tool in ecology, but are clearly influenced by many external factors which should be taken in account (Sierzen et al. 2006; Xu et al. 2007; Bouillon et al. 2008; Hyodo et al. 2008). Irrigation ponds can be filled with water originating from water river transfers, sewage or desalination plants, which may represent one source of isotopic variability. In our case, $\delta^{15} \mathrm{~N}$ values were directly related to the concentration of nitrates in water. Increased $\mathrm{NO}_{3}$ concentration already brought about an increase in the $\delta^{15} \mathrm{~N}$ values for the invertebrates living in an intensive agriculture area (Cremona et al. 2009), and a similar result was observed for $\mathrm{NH}_{4}{ }^{+}$(Owens 1987). Another important driver of source variability for $\delta^{15} \mathrm{~N}$ values is pollution deriving from urban sewage and agriculture (Fair, and Heikoop 2006). Eutrophication can also produce temporal changes in the $\delta^{15} \mathrm{~N}$ values of sediments (Hyodo et al. 2008) and can increase the $\delta^{15} \mathrm{~N}$ isotopic values for macrophytes, as already identified as indicators of wastewater inputs and eutrophication (Cole et al. 2004). The organic nitrogen concentration and COD also correlate with the $\delta^{15} \mathrm{~N}$ values for both macrophytes and macroinvertebrates. We also report that the significance of the model, which relates COD with the $\delta^{15} \mathrm{~N}$ values, is higher for floating than for submerged macrophytes. This may be due to differences in the nitrogen uptake rates in preference for $\mathrm{NO}_{3}{ }^{-}$or $\mathrm{NH}_{4}^{+}$ in both internal nitrogen cycling rates and nitrogen sources. Conductivity has been identified as a cause of variability in the $\delta^{13} \mathrm{C}$ values for shrimps, barnacles and anchovies (Wissel, and Fry 2005) and, as in the study system, it can also affect the $\delta^{15} \mathrm{~N}$ isotopic values (Mariotti et al. 1983).

In our system, none of the water chemical characteristics correlates with the $\delta^{13} \mathrm{C}$ values for macrophytes and invertebrates. Variability may relate more to differences in the degree of development, metabolic routes or the carbon sources used, which are typical of each organism.

One possible explanation for isotopic variability probably relates to ponds management. Herbicides and algaecides are often used in irrigation ponds to control the growth of algae and macrophytes as they can block irrigation tubes (Sánchez-Zapata et al. 2005). As in previous studies (Caquet 2006), isotopic changes may relate to variations in the carbon and nitrogen fluxes across food webs in treated ponds, associated with shifts in the phytoplankton community structure.

As a result of human management, some ponds do not receive additional water for many months, whilst in other cases (the majority), ponds are refilled more frequently for agricultural purposes. Hence, water characteristics vastly fluctuate between ponds, and the system can be used to analyse possible sources of variability in $\delta^{15} \mathrm{~N}$ and $\delta^{13} \mathrm{C}$ values driven by the effect of some biogeochemical processes. For example, in those ponds that do not undergo water renewal, photosynthesis preferentially consumes ${ }^{12} \mathrm{C}$, which provokes a ${ }^{13} \mathrm{C}$ enrichment trend in DIC. In fact, the isotopic values of DIC in some ponds provide extremely positive isotopic values in $\delta^{13} \mathrm{C}$ (DIC ranging between 9.4 and $+0.4 v s$ V-PDB; authors, unpublished results). Consequently, macrophytes and macroinvertebrates provide high isotopic values in some individual ponds. This coincides with long periods between water renewals. The $\delta^{13} \mathrm{C}$ values for macrophytes range from 15 to $10 \%$, indicating that water has distinctly positive DIC values.

Moreover, it is difficult to explain some of the extremely high $\delta^{15} \mathrm{~N}$ values $(+25.0 \%)$ and the average values for macrophytes of $+10.8 \%$ only in terms of either the chemical differences in the water or the effect of excrement. Only general denitrification processes can account for these relatively high average values in primary producers such as macrophytes, which clearly stand out from the remainder of the trophic chain. The favourable temperatures for biological activity and the relatively high residence times of water in some ponds (which agree with the high isotopic $\delta^{13} \mathrm{C}$ values in DIC) can account for the high levels of denitrification bacteria required to justify these extreme isotopic $\delta^{15} \mathrm{~N}$ values. ${ }^{15} \mathrm{~N}$ enrichment may be due, on the one hand, to the bio-geochemical transformation of inorganic fertilisers (nitrate and urea) and further nitrification. On the other hand, enrichment may be 
caused by the denitrification processes which generate $\mathrm{N}_{2} \mathrm{O}, \mathrm{NO}_{3}, \mathrm{NO}_{2}$ and $\mathrm{N}_{2}$, where each reaction product is impoverished in ${ }^{15} \mathrm{~N}$ and the residual $\mathrm{N}$-component is enriched in ${ }^{15} \mathrm{~N}$ (Mariotti et al. 1988; Robinson 2001). A continuous loss of volatile components (impoverished in ${ }^{15} \mathrm{~N}$ ) may explain the relatively high $\delta^{15} \mathrm{~N}$ values reached. The use of chemicals that stop the growth of algae, lowers photosynthesis and, therefore, the contribution of oxygen from the water molecule, leading to a more reducing systems (eutrophic waters), which favors denitrifying bacteria. This results in an increase in the release of gases $\left(\mathrm{N}_{2}\right.$, $\mathrm{N}_{2} \mathrm{O}$ ) impoverished in ${ }^{15} \mathrm{~N}$, which enriches the nitrogen compounds remaining in the water.

The ponds seem to have undergone fractionation processes, as described by Rayleigh (1896); that is, loss of gases containing lighter nitrogen (impoverished in ${ }^{15} \mathrm{~N}$ ) with organic material production by macrophytes (impoverished in ${ }^{13} \mathrm{C}$ owing to photosynthesis) preferentially take those molecules containing the lighter isotope from the system. This isotopic effect may have underpinned the large isotopic variability observed in these systems and, hence, the extremely enriched isotopic values recorded in these waters. Further research into the residence time of the water in the pond with isotope values would be interesting to confirm this theoretical explanation of variability.

\section{Guano influence}

External nitrate inputs can derive from not only anthropogenic (such as sewage systems or an agricultural origin), but also other biotic sources, such as avian guano (Fujita, and Koike 2007; Keatley et al. 2009). Our study system identifies the use of irrigation ponds by Larid species could be behind the increment in the $\delta^{15} \mathrm{~N}$ isotopic values recorded for macrophytes, which are located at the bottom of the food web. Nevertheless, this relationship was not found for macroinvertebrates. The differences in the fractionation among trophic levels can shape this effect. Moreover, the significance of Larids' influence on the isotopic values for macrophytes high-lights the importance of these species in connecting patches. The movements of these individuals may transport nutrients in the natural and artificial wetlands net-work. These birds act as linking points between the natural wetlands where they breed and the irrigation ponds they use for foraging purposes.

It is also important to notice that, even if we have found a relationship between larid presence and nitrate increase, we could not differentiate whether this nitrate had an organic origin (it comes from the larids' guano) or if it is inorganic and it is related to the use of fertilizers by the pond owners (Sánchez-Zapata et al. 2005), which is a common practical at the area. Further analyses would be interesting to clarify this question.

\section{CONCLUSIONS}

Macroinvertebrates and macrophytes in irrigation ponds are highly variable in terms of their $\delta^{13} \mathrm{C}$ and $\delta^{15} \mathrm{~N}$ isotopic values, even within the same species in different ponds. This variability can be explained by the chemical water characteristics. We found significant relationships between water conductivity and the $\delta^{15} \mathrm{~N}$ isotopic values for macrophytes, and also with nitrates, organic nitrogen concentrations and COD (Chemical Oxygen Demand). We also detected clear relationships among bicarbonates, ammonium and COD for the macroinvertebrate $\delta^{15} \mathrm{~N}$ values. The anthropogenic influence on each pond's biogeochemical evolution leads to important isotopic variations in both DIC (Dissolved Inorganic Carbon) and dissolved nitrates which, in turn, are reflected in the different local trophic chain elements. Finally, the existence of external nitrate inputs from Larid excrements was also related with the $\delta^{15} \mathrm{~N}$ values recorded for macrophytes.

\section{ACKNOWLEDGMENTS}

This study was funded by the Generalitat Valenciana through the I+D project CTIDIB/2002/142 and by the Conselleria de Territori i Habitatge. A. Granados and A. Asencio helped with the stable isotope analyses and with the identification of the macrophytes, respectively. C. Gutierrez and A. Millán assisted with the macroinvertebrates' classification. C. Villacorta helped during the fieldwork. We are grateful to F. Hiraldo for his help. E. Sebastián-González benefited from a FPU grant from the Ministry of Education. J. Navarro was supported by a postdoctoral contract of the Juan de la Cierva program (MICINN-JDC, Spanish Ministry of Science and Innovation). Two anonymous reviewers provided interesting comments on the manuscript.

\section{REFERENCES}

Abellán P, Sánchez-Fernández D, Millán A, Botellam F, Sánchez-Zapata JA, and Giménez A. 2006. Irrigation ponds as macroinvertebrate habitat in a semi-arid agricultural landscape (SE Spain). J. Arid Environ. 67: 255-269.

Alexander SA, Hobson KA, Gratto-Trevor C, and Diamond AW. 1996. Conventional and isotopic determinations of shorebird diets at an inland stopover: the importance of invertebrates and Potamogeton pectinatus turbers. Can. J. Zool. 74: 10571068.

Bouillon S, Connolly RM, and Lee SY. 2008. Organic matter and cycling in mangrove ecosystems: Recent insights from stable isotope studies. J. Sea Res. 58: 44-58.

Cabana G, and Rasmussen JB. 1996. Comparison of aquatic food chains using nitrogen isotopes. Proc. Nat. Acad. Sci. USA, 93: 10844-10847.

Caquet T. 2006. Use of carbon and nitrogen stable isotope ratios to assess the effects of environmental contaminants on aquatic food webs. Environ. Pollut. 141: 54-59.

Céréghino R, Biggs J, Oerti B, and Declerck S. 2008. The ecol- 
ogy of European ponds: defining the characteristics of a neglected freshwater habitat. Hydrobiologia 597: 1-6.

Cole ML, Valiela I, Kroeger KD, Tomasky GL, Cebrian J, Wigand C, McKinney RA, Grady SP, and Silva MEC. 2004. Assessment of a $\delta^{15} \mathrm{~N}$ isotopic method to indicate antropogenic eutrophication in aquatic ecosystems. J. Environ. Qual. 33: 124-132.

Cremona F, Planas D, and Lucotte M. 2010. Influence of functional feeding groups and spatiotemporal variables on the $\delta^{15} \mathrm{~N}$ signature of littoral macroinvertebrates. Hydrobiologia 647: 51-61.

De Meester L, Declerck S, Stoks R, Louette G, van de Meutter F, de Brie T, Michels E, and Brendonck L. 2005. Ponds and pools as model systems in conservation biology, ecology and evolutionary biology. Aquat. Conserv. 15: 715-725.

Dunton KH. 2001. $\delta^{15} \mathrm{~N}$ and $\delta^{13} \mathrm{C}$ Measurements of Antarctic Peninsula Fauna: Trophic Relationships and Assimilation of Benthic Seaweeds. Am. Zool. 41: 99-112.

Fair J, and Heikoop JM. 2006. Stable isotope dynamics of nitrogen sewage effluent uptake in a semi-arid wetland. Environ. Pollut. 140: 500-505.

Finlay JC, and Kendall C. 2007. Stable isotope tracing of temporal and spatial variability in organic matter sources to freshwater ecosystems. In: R. Michener, and K. Lajtha (Eds), Stable isotopes in ecology and environmental science. Blackwell Publishing: London, UK: pp. 283-374.

Finlay JC, Khandwala S, and Power ME. 2002. Spatial scales of carbon flow in a river food web. Ecology 83: 1845-1859.

Fujita M, and Koike F. 2007. Birds transport nutrients to fragmented forests in an urban landscape. Ecol. Appl. 17: 648654.

Fry B.1991. Stable isotope diagrams of freshwater food webs. Ecology 72: 2293-2297.

Gichuki J, Triest L, and Dehairs F. 2001. The use of stable carbon isotopes as tracers of ecosystem functioning in contrasting wetland ecosystems of Lake Victoria, Kenya. Hydrobiologia 458: 91-97.

Grey J, Kelly A, Ward S, Sommerwerk N, and Jones RI. 2004. Seasonal changes in the stable isotope value of lakedwelling chironimid larvae in relation to feeding and life cycle variability. Freshwater Biol. 49: 681-689.

Haney JC, Kerr C, Golovkin AN, and Flint MV.1998. Utilization of nitrogen derived from seabird guano by terrestrial and marine macrophytes at St. Paul, Pribilof, Bering Sea, Alaska. Mar. Biol. 131: 63-71.

Harvey CJ, and Kitchell JF. 2000. A stable isotope evaluation of the structure and spatial heterogeneity of a Lake Superior food web. Can. J. Fish. Aquatic Sci. 57: 1395-1403.

Howard JK, Cuffey KM, and Solomon M. 2005. Toward using Margaritifera falcata as an indicator of base level nitrogen and carbon isotope ratios: insights from two California Coast Range rivers. Hydrobiologia 541: 229-236.

Hamilton SK, Lewis Jr WM, and Sippel SJ. 1992. Energy sources for aquatic animals in the Orinoco River flood-plain: Evidence from stable isotopes. Oecologia 89: 324-330.

Hobson KA. 1995. Reconstructing avian diets using stable-carbon and nitrogen isotope analysis of egg components: patterns of isotopic fractionation and turnover. Condor 97 : 752-762.

Hobson KA, and Welch HE. 1992. Determination of trophic re- lationships within a high Arctic marine food web using stable-isotope analysis. Mar. Ecol. Progr. Ser. 84: 9-18.

Hyodo F, Tsugeki N, Azuma J, Urabe J, Nakanishim M, and Wada E. 2008. Changes in stable-isotopes, lignin-derived phenols and fossil pigments in sediments of Lake Biwa, Japan: Implications for anthropogenic effects over the last 100 years. Sci. Tot. Environ. 403: 139-147.

Kao WY, Tsai HC, and Tsai TT. 2001. Effect of $\mathrm{NaCl}$ and nitrogen availability on growth and photosynthesis of seedlings of a mangrove species, Kandelia candel (L.) Druce. J. Plant Physiol. 158: 841-846.

Keatley BE, Douglas MSV, Blais JM, Mallory ML, and Smol JP. 2009. Impacts of seabird-derived nutrients on water quality and diatom assemblages from Cape Vera, Devon Island, Canadian High Arctic. Hydrobiologia 621: 191-205.

Kelly JF. 2000. Stable isotopes of carbon and N in the study of avian and mammalian trophic ecology. Can. J. Zool. 78: 127.

Mariotti A. 1983. Atmospheric nitrogen is a reliable standard for natural $15 \mathrm{~N}$ abundance measurements. Nature 303: 685-687.

Mariotti A, Landreau A, and Simon B. $1988 .{ }^{15} \mathrm{~N}$ isotope biogeochemistry and natural denitrification process in groundwater: application to the chalk aquifer of northern France. Geochim. Cosmochim. Acta 52: 1869-1878.

McCullagh P, and Nelder JA. 1989. Generalised Linear Modelling. Chapman and Hall, London, 512p.

Michener RH, and Scherr DM. 1994. Stable isotopes as tracers in marine aquatic food webs. In: K. Lajtha, and R. Michener (Eds), Stable isotopes in ecology and environmental science. Blackwell Scientific Publications. Oxford, UK: 138-185.

Owens NJP.1987. Natural variations in $15 \mathrm{~N}$ in the marine environment. Adv. Mar. Biol. 24: 389-451.

Post HM. .2002. Using stable isotopes to estimate trophic position: models, methods, and assumptions. Ecology 83: 703718.

R Development Core Team. 2005. R Development Core Team, R: A Language and Environment for Statistical Computing. R Foundation for Statistical Computing. Vienna, Austria.

Rayleigh JWS. 1896. Theoretical considerations respecting the separation of gases by diffusion and similar processes. Philos. Mag. 42: 493-498.

Robinson D. 2001. ${ }^{15} \mathrm{~N}$ as an integrator of the nitrogen cycle. Trends Ecol. Evol. 16: 153-162.

Sánchez-Zapata JA, Donázar JA, Delgado A, Forero MG, Ceballos O, and Hiraldo F. 2007. Desert locust outbreaks in the Sahel: resource competition, predation and ecological effects of pest control. J. Appl. Ecol. 44: 323-329.

Sánchez-Zapata JA, Anadón JD, Carrete M, Giménez A, Navarro J, Villacorta C, and Botella F. 2005. Breeding waterbirds in relation to artificial pond attributes: implications for the design of irrigation facilities. Biodivers. Conserv. 14: 1627-1639.

Sebastián-González E, Sánchez-Zapata JA, and Botella F. 2010. Agricultural ponds as alternative habitat for water-birds: spatial and temporal patterns of abundance and management strategies. Eur. J. Wildl. Res. 56: 11-20.

Sierzen ME, Peterson GS, Trebitz AS, Brazner JC, and West CW. 2006. Hydrology and nutrient effects on food-web structure in ten Lake Superior coastal wetlands. Wetlands 26: 951-964. 
Søreide JE, Hop H, Falk-Petersen S, Hegseth EN, and Carroll ML. 2006. Seasonal food web structures and sympagicpelagic coupling in the European Arctic revealed by stable isotopes and a two-source food web model. Progr. Oceanogr. 71: 59-87.

Spencer CN, Gabel KO, and Hauer FR. 2003. Wildfire effects on stream food webs and nutrient dynamics in Glacier National Park, USA. Forest Ecol. Manag. 178: 141-153.

Syväranta J, Hämäläinen H, and Jones RI. 2006. Within-lake variability in carbon and nitrogen stable isotope signatures. Freshwater Biol. 51: 1090-1102.

Tamelander T, Renaud PE, Hop H, Carroll ML, Ambrose Jr WG, and K. Hobson. 2006. Trophic relationships and pelagicbenthic coupling during summer in the Barents Sea Marginal Ice Zone revealed by stable carbon and nitrogen isotope measurements. Mar. Ecol. Progr. Ser. 310: 33-46.

Tavares PC, Kelly A, Maia R, Lopes RJ, Serrão Santos R, Pereira ME, Duarte AC, and Furness RW. 2008. Variation in the mobilization of mercury into Black-winged Stilt $\mathrm{Hi}$ mantopus himantopus chicks in coastal saltpans, as revealed by stable isotopes. Estuar. Coast Shelf. Sci. 77: 65-76.

Vander Zanden MJ, and Rasmussen JB.1999. Primary consumer $\delta^{13} \mathrm{C}$ and $\delta^{15} \mathrm{~N}$ and the trophic position of aquatic consumers. Ecology 80: 1395-1404.

Wissel B, and Fry B. 2005. Tracing Mississipi River influences in estuarine food webs of coastal Louisiana. Oecologia 144: 659-672.

Xu J, Zhang M, and Xie P. 2007. Stable carbon isotope variations in surface bloom scum and subsurface seston among shallow eutrophic lakes. Harmful algae 6: 679-685. 